\title{
Knowledge and Perception of Cord Blood Bank among
}

\section{Lebanese Population}

\author{
Bassam Charif Hamdar ${ }^{1 *} \&$ Rita Abla ${ }^{2}$ \\ ${ }^{1}$ Faculty of Business and Economics, Department of Economics, American University of Science and \\ Technology, Beirut, Lebanon \\ ${ }^{2}$ Faculty of Health Sciences, Dean's office, American University of Science and Technology, Beirut, \\ Lebanon \\ *B Bassam Charif Hamdar, E-mail: bhamdar@aust.edu.lb
}

\begin{abstract}
The cord blood cells are hematopoietic stem cells which can differentiate only into blood cells. In other words, cord blood stem cells are blood cell precursors which can form red blood cells, white blood cells, and platelets. Nowadays, these cells are being used to treat blood and immune system that associated with genetic diseases, cancers, and blood disorders.

Due to the great value of the stem cells, new research and technology show that it is highly recommended that cord blood cells are reserved for the future use. This paper will shed light on the important aspects and the ability of doing blood cord bank in Lebanon.

This paper is exploratory in nature and its mere purpose is to focus on some aspects that were first not known in the Arab world in general and in Lebanon in specific. To achieve all the above, a questionnaire has been designed and delivered to the sample via different means.

An overview of this paper reveals some understanding about the level of awareness achieved by the Lebanese citizens. Other objectives came into play and some of those were the relation between banking cord blood and religion.
\end{abstract}

The outcome of this paper is a practicability study of blood cord bank which is related two concepts, with and against, by revealing the pros and cons of this subject.

\section{Keywords}

cord blood bank, Lebanese population, Arab World, religion, the level of education

\section{Introduction}

Cord blood contains stems cells kept at a certain temperature, and can be used to treat malignant and non-malignant diseases, including hematological cancers and thalassemia. The process of cord blood banking is easier and faster in finding a tissue match, but also has a smaller possibility of recipient rejection, than found in traditional bone marrow transplants (Moise, 2013).

Cord blood, also called placental blood, is found in the umbilical cord and placenta of newborn babies. 
After birth, the umbilical cord is cut and usually discarded and the infant will no longer get benefit from the blood remaining in this organ. Cord blood has the same components as that of the other blood available in any organ. However, it is distinguished by the overabundance of hematopoietic cells in it. Hematopoietic are immature, or primitive, cells which still have the potential to form into platelets, or red or white blood cells. With some scientific intervention, they may even be able to form into other cell types that make up your body (Bou Youness, 2014).

Hematopoiesis is the natural process of generating healthy blood cells. Prenatally, it takes place in the yolk sack, liver and bone marrow, consecutively. However, after birth, hematopoiesis occurs in the bone marrow only. Both bone marrow and cord blood serve for transplantation purposes; however they have the following differences. Isolating bone marrow is a very painful procedure and necessitates gathering samples from a healthy matching donor in order to treat a disease (Drgreen, 2005). On the contrary, banking cord blood allows for bypassing such obstacles whereby the procedure of cord blood samples is easy and non-painful. Moreover, cord blood saved for personal use doesn't require finding a donor match. The number of Hematopoietic Stem Cells (HSC) originated from the bone marrow or peripheral blood HSC donation is around one log greater than that available in the cord blood; however the latter has greater proliferative and colony forming capacity, and is more responsive to some growth factors. Finally, the complications associated with some aspects of HSC transplantation is greater in the case of bone marrow transplantation than in cord blood transplants because the latter have more "naive" than proliferative cells from bone marrow (due date calculator, 2013).

\section{Need for the Study}

This subject up to this day is still believed to lack awareness by the population and hence this research seeks to question several sides related to banking cord blood such as the relation among the educational level, financial ability, religion, willingness to bank cord blood and others such as the suitability of the Lebanese environment for banking.

\section{Problem Definition}

Despite the fact that the concept of cord blood banking is still not very popular in the Lebanese environment, it is believed by many in its power to save lives. This belief unfortunately has not been translated into action through the evident lack or even absence of cord blood banks or corporations. Moreover, we can't consider Lebanon as a suitable environment for cord blood banking. On the other hand; people have always been influenced by religion whether in a direct or indirect way. This religion influence affects childbirth and may affect decision to bank or not to bank cord blood. The process of Blood Cord Banking costs money. Hence; the family's financial income will play an important aspect in pursuing banking of cord blood. The controversy pertaining to this subject will not vanish but should the controversy affect people's minds, influence their decisions, and forbid them from banking their 
babies' cord blood? This is the question under study.

\section{Literature Review}

The concept of Cord blood being stored began with Edward Boyse in 1983; he was the first to introduce the concept of using the umbilical cord blood as a source of stem cells for hematopoietic transplantation. The first step towards initiating an umbilical cord blood bank was attempted at Indiana University which collected cells from siblings of children requiring transplants. Then in 1988, Elaine Gluckman and her team conducted the first related transplant with umbilical cord blood in Paris-France on a six year old kid suffering from Fanconi anemia by using one of these collected blood units. A year after, the first related umbilical cord blood transplant was conducted in the United States (Cordblood, 2013).

In New York Blood Center, the first public bank for umbilical cord blood was established in 1991. This bank was funded by the National Heart, Lung, and Blood Institute of the National Institutes of Health (NIH). Then in 1996, the NIH has granted a multicenter award to umbilical cord blood banks and transplant centers in order to assess the safety and efficiency of umbilical cord blood transplants (American Pregnancy Association (APA), 2013)

\section{Definition}

Cord blood banking involves collecting blood left in newborn's umbilical cord (the part of the placenta that delivers nutrients to a fetus) and storing it for future medical use (Baby Center.ca, 2012). Collecting cord blood is painless and safe for mother and baby. It doesn't interfere with birth plans, and still allows the father-if he wants - to cut the umbilical cord (Cordblood, 2013).

The first successful umbilical cord origin cell transplant was accomplished in 1988 in treating Fanconi's anemia a genetic disorder. Cord blood contains blood-forming stem cells (the building blocks of blood and immune system) (Baby center, 2012).

Stem cells have the ability to develop and transform into other types of cells in the body, so they can help repair tissues, organs, blood vessels and provide physicians with a way to treat many diseases (APA, 2013). These cells are mainly useful for treating diseases that require stem cell transplants (also called bone marrow transplants), such as certain kinds of leukemia or lymphoma, aplastic anemia, severe sickle cell disease, and severe combined immunodeficiency (Ben-Joseph, 2012).

As mentioned above, cord blood stem cells have similar abilities to treat diseases as bone marrow but with significantly less rejection (APA, 2013). Unlike the stem cells in bone marrow, stem cells in cord blood are immature and are not ready to attack foreign substances. Similarly, the body doesn't recognize these "primitive" cells as foreign. As a result, patients who receive stem cells from cord blood are less likely to suffer transfusion rejection (Baby center, 2012).

Banking a baby's blood and stem cells in a cord blood bank is a type of insurance. Cord blood bank can 
offer security to the family, knowing that a valuable reserve is available upon request. The stem cells from your baby's cord blood may be successful in treating certain diseases or conditions that may even affect a parent or sibling (Bill, 2013).

In general, two payments are applied in cord blood banking. The first payment covers the registration, gathering and storage of the collected samples. The second payment is the storage fee. The initial fee can range from $\$ 1500$ to $\$ 2000$. The storage fees can be collected later (after the delivery) based on a contract agreement between the parents and the representative company (Bou Youness, 2014). Cord blood banks usually encourage people to do the initial storage by offering prepaid plans at a discount and payment plans (Ben-Joseph, 2012). Moreover there are banks that offer a loan program in order to arrange the initial payment (Nehmeh, 2013).

\section{Components}

There are both private and public cord blood banks. Some facilities may offer both services, but the samples are particularly devoted for one use or another. In both cases, the mother should sign a contract-agreement form however; the conducted testing of the mother and samples might vary (Ben-Joseph, 2012).

Private Banks process and store the Umbilical Cord Blood (UCB) specifically for the customer (donor and/or family). They are not associated with any particular hospital. Consequently, the bank provides the mother with samples collection kit containing the materials needed for collection and shipping to the processing facility (collection bag, labels, etc.). The mother should handle the kit to the health care provider on the day of delivery (Cordblood, 2013).

In private banks, both the customer (donor) and the bank should sign a contract which specifies the details of the preparations, including transport, shipping responsibilities, proprietorship and liability issues. At first, the customer pays initial processing fees and then an annual storage fees are applied. The tests performed on the samples which are saved for private use (within the family only) vary among private banks. For instance, the collected blood unit might or might not be subject to certain tests such as donor screening, tissue typing. It is good to mention that units stored in a private bank cannot be "crossed over" for public use (American Association of Blood Banks (AABB), 2013).

In contrast to private banks, UCB products collected by public banks are processed and stored for public use. Each individual has a unique tissue or type of Human Leukocyte Antigen (HLA) (Ben-Joseph, 2012). Similarly, each UCB donation represents a unique combination of tissues or HLA originated from the parents of the donor. Therefore, each UCB unit has a specific type of HLA and a defined cellular content. This information is entered into a database that physicians have access to when looking for a patient "match". These products are available to anyone who needs them and does not have UCB back up. Public cord blood banks do not charge a fee to the donor; instead they recuperate their costs by charging the patient a fee when the unit is used (AABB, 2013). 


\section{Process}

The cord blood should be processed and stored in a facility that is accredited by the American Association of Blood Banks (2013) for the purpose of handling stem cells.

When the baby is delivered (vaginally or via $\mathrm{C}$-section) the umbilical cord is clamped and cut where a part of the cord remains attached to the placenta. Subsequently, the medical provider collects cord blood by inserting a needle into the umbilical vein of the attached part of the cord. The needle doesn't go anywhere near the baby (Columbo, 2012).

A medical provider can use either the syringe or the bag method for blood collection as follows (Wolf, 1998, p. 5):

Syringe method: the medical provider uses a syringe to withdraw blood from the umbilical cord shortly after it has been cut. This procedure is similar to that of collecting blood samples for routine medical testing.

Bag method: the medical provider collects blood by hanging a blood donation bag in a position lower than the mother, so that the gravity allows the blood to be drawn down into the bag.

Prior to blood collection, the syringe or bag should be labelled with an identifier unique to each baby. The cord blood should be collected within 15 minutes after delivery. The laboratory should then process the drawn blood within 48 hours of collection (APA, 2013).

Typically, the average size of the collected cord blood samples is 3 to 5 ounces (50 to $200 \mathrm{ml}$ ). The blood collection procedure usually requires less than ten minutes. Following collection, the blood is dispatched to a cord blood bank, where it is analyzed, treated and frozen for long-term storage while complying with quality standards (Baby center, 2012).

In addition to saving cord blood, several private cord blood banks are now providing the option of storing a segment of the umbilical cord because it contains stem cells that are not available in the cord blood. Researchers are currently investigating the possible usages of the umbilical cord stem cells (Baby center, 2012).

When a UCB product is received to the cord blood bank, it is given a unique identification code which is mainly represented by numbers instead of names for confidentiality purposes. Then, the quantity of blood-forming cells is checked to see if it is sufficient for curing process. Further, the sample is tested to be sure that it is free from contamination; and analyzed by HLA-typing in order to assess the compatibility level which is required to be known when transplantation is needed in the future. Subsequently, it is subject to the removal of red blood cells before storage. This process is called red blood cell reduction and it is adopted by the majority of cord blood banks (Percer, 2009). Reducing red blood cells is very crucial before freezing the sample, because if these cells are remained in the sample they might cause post-transplant complications such as anemia, jaundice, and shock. It is worth mentioning that red blood cells don't constitute a part of the stem cell population in the baby's cord blood. Consequently, they have little effect on the target cells which are needed to be saved (Cordblood, 
2013). At the end, the sample will be frozen in a liquid nitrogen freezer and stored (Bill, 2013).

Once stored, UCB is available for a transplant when the patient needs it. (If it is in a private bank) then the sample is ready to be used whenever the baby needs it. If the sample is in a public bank then the physicians will search among the donated cord blood units and the bone marrow donors on the Match Registry to find a match to locate the most compatible sample for the patients (Bill, 2013).

\section{Advantages}

The frequency of using cord blood has importantly increased since year 2000. Consequently, the probability of needing stem cells transplants by any of the family members is increasing as well (National Cord Blood Program, 2010). According to the newest surveys, the probability of requiring a stem cell transplant is 1 in 217. Nowadays, more than 30 FDA-regulated clinical trials are investigating the uses of UCB stem cells in treating many diseases (Moninger, 2010).

Cord blood serves as a good source of hematopoietic stem cells that are used in medical transplantation treatments which are conduct to cure life-threatening disorders. Families with medical history belong to minor or mixed ethnics or have an adopted newborn, are advised to do cord blood bank in order to be provided with an efficient resource against potential disorders that might occur in the future. Nowadays a huge number of new parents, nurses, physicians and scientists enroll each month in the cord blood banks in order to save their infants stem cells. The main reasons for saving cord blood are summarized below (Percer, 2009, p. 218):

Parents to-be face an interesting dilemma of whether or not to do cord blood banking of their unborn child. There are several advantages to storing umbilical blood of the newborn as it has been proven to be life-saving in many cases where the child had life-threatening conditions and there has been a lot of research on the topic (Colombo, 2012).

Cord blood stem cells have been successfully used in transplant medicine for more than 20 years. It has been used to treat many life-threatening diseases including leukemia, other cancers, blood disorders, metabolic disorders, and immune diseases. Cord blood also is being used in regenerative medicine research, where stem cells are being evaluated for their ability to induce healing and regenerate cells to repair tissues. Clinical trials are evaluating a child's own cord blood stem cell infusions as experimental therapies to treat cerebral palsy, brain injury, juvenile diabetes, and acquired hearing loss (Cordblood, 2013).

The saved cord blood of a certain child remains available for all family members in case it is required for a specific treatment. Moreover, conducting transplantation via a related cord blood has significant potential advantages over that via an unrelated donor. Such advantages include fewer complications and better medical results. Additionally, cord blood banking permits avoiding pain induced by bone marrow harvest surgery and saves time as well. It is worth mentioning that when a disease is treated at an early stage, its rate of progression will be minimal (Alkindi \& Dennison, 2011, p. 457). 
It is essential to mention that the stem cells of the child himself/herself cannot be used in specific inherited genetic disorders. In such cases, doctors look for matched stem cells from the child's siblings; though, none can guarantee that a perfect match will be found. Using cord blood from donors of the same family will allow decreasing the potential complications and improving medical results. Furthermore, saving cord blood for all family members is essential in participating in clinical trials that require having the child's own stem cells (Epigee, 2013). Accordingly, the possibility of finding a suitable donor in the case of cord blood transplantation is much higher than that of bone marrow grafting.

It does not need a perfect match. This is the biggest advantage. Cord blood can be transplanted even if there is only a partial match between donor and recipient. As well as, the recipient is at fewer risks of complications by cord blood transplant. The immune cells present in cord blood are less likely to attack the tissue of a patient (graft vs. host disease) as compared to bone marrow transplant. Also, cord blood is less likely to spread certain viruses such as cytomegalovirus (CMV) and Epstein-Barr Virus (EBV), which are deadly infections that strike transplant recipients (National Cord Blood Program, 2010).

\section{Disadvantages}

Although it's called umbilical cord blood banking, what you are really banking is your baby's stem cells. The stem cells can be used in a variety of treatments from Parkinson's disease to growing replacement organs. By banking the stem cells, you give your baby a form of medical insurance should the child ever develop a problem that can be cured through stem cells. Some of the disadvantages include, even though the transplantation is antilogous, then donated cord blood is of little use (Ballen, 2010, p. 10).

As well as, the collection and storage charges of private banks can be very high and out of reach for many people. Saving a child's life is, of course, priceless, the research does not, at this time, support the idea that cord blood banking is more helpful in saving a child's life than are other methods that are less expensive (Cameron, Lorena, \& Kerridge, 2013, p. 290).

It's noteworthy to mention, the Stem cells are separated from the blood and then frozen at -196 degrees $\mathrm{C}^{\circ}$. It is unknown how long stem cells can be kept frozen, although some stem cells have survived being frozen for twenty years (Ballen, 2010). Moreover, most cures requiring stem cells come from bone marrow and not from stem cells. Stem cells can be found in other parts of the body, such as the testicles. Thus, it validates the cause of saving the Cord Blood.

If you choose not to store your children's cord blood and they have a medical condition, this does not mean that there is no treatment available to you. Regular bone marrow transplants with a matching donor are still an option, as is finding a cord blood match through a public cord blood bank. It is important to understand these options so that you don't make a decision based on fear or future regret (Cameron et al., 2013, p. 291). Cord blood banking doesn't provide enough stem cells to complete an 
adult's transplant needs. So, the stored stem cells are only helpful in the event that a child in the family becomes ill (Moise, 2005).

Research has not proven that the benefits of the stem cells taken from a relative are higher than those taken from an unrelated donor (Epigee, 2013). While it is reassuring to know that those stem cells would be there for your family, should you need them, research indicates that you would have just as much success receiving stem cells from an unknown donor as you would from a family member (Hess, 1997).

These are some of the main disadvantages at the moment to storing cord blood. This is a relatively new field, and the medical profession has only been storing cord blood since the 1970s. Some argue that it is important to store cord blood now in the hopes that future research will yield more life-saving purposes for the cord blood. While this is a possibility, it's not necessarily a valid enough point for the cost of storing cord blood today. It is certainly important to know the facts about private cord blood banking and to become educated before making this decision. Try to make an informed decision, and one that will make you comfortable — emotionally, physically and financially — for years to come (Alkindi et al., 2011, p. 460).

To sum up, the volume of cord blood collection is relatively small. Hence, the quantity of stem cells available for transplantation is less than that in peripheral blood or bone marrow. This problem is greater for adults and adolescents, as they need comparatively more quantity of stem cells for transplant. Cord blood transplantation exposes the patient to one of the rare genetic disorders of the immune system or blood. This disorder is not detectable while testing the cord blood sample, as it remains invisible in the child for many years. However, the chance of getting this disorder is less than 1 in 10,000 (Hess, 1997, p. 80).

The donor cord blood stem cells come from a newborn baby and are unavailable for extra cord blood donation. Therefore, if the first cord blood unit fails, the second unit will have to be obtained from a different donor (Ballen, 2010, p. 11). Just as every coin has two sides, so does umbilical stem cell cord blood? But, it promises to provide the solution to many critical medical conditions.

Cord blood banking is gaining prominence day by day. However, before we consider cord blood collection and cord blood transplant, we should be aware of the benefits of this process for the recipient. However, it may take a decade or two before there is a definite cure to deadly diseases. Nevertheless, researchers are busy researching on stem cells in the hope of making it a powerful medical tool in the coming years (Wolf, 1998).

\section{Cord Blood Controversy}

Main concern for private banking is that your child might not be able to use his or her own cells depending on the type of the developed disease. Some types of disease are genetic disorders which result from change(s) in the individual's DNA; i.e., they are present in all cells of this individual (Percer, 
2009).

There are certain cases where a child's own cord blood can't be used to treat him, even when he's young. Childhood Example of such cases is the childhood leukemia disease which is cured with chemotherapy alone since in such cases the DNA will be affected even in the stem cells. Some private banks are trying to show that the cord blood is important in the treatment of this disease. If a transplant is needed, doctors wouldn't use a child's tainted cord blood (Walter-Wise, 2011, p. 54).

It would be possible for a healthy child's cord blood to be used to treat a sibling. But, even if a sick child has a sibling donor, there's only a 25 percent chance that cord blood will be a perfect match - and an equal chance it won't match at all. Knowing that a certain number of compatibility factors are tested and there is a cut-off acceptance. Therefore, you should think about the chances of your child getting a serious medical illness (Nehmeh, 2013).

Very few cord-blood transplants have been given to adults because most units haven't contained enough stem cells to treat anyone weighing more than 90 pounds (around $40 \mathrm{kgs}$ ), therefore, you can rarely transplant an adult with a cord blood unit. And Like any transplant, finding a suitable match can sometimes be a challenge. Moreover, the procedure is relatively new; no one knows how many years the frozen units will remain viable (Nehmeh, 2013).

The shocking truth is that the most of cord blood samples that are stored in private banks might not be usable in the future; meaning that an individual might not be able to get benefit of the blood which he has paid for it is storage (Moninger, 2010).

There are a lot of factors to consider when it comes to banking your child's cord blood. For instance, an individual pays high amount of money for saving a cord blood sample at the time where the probability of using the stored sample is very low. However, if one day the family needed to use the save sample, then it would be a worth investment. This is a family decision that should be made considering all the facts. Finally, if a person decided not to go for private banks, it is important that he/she considers public banks; especially that his/her donations might be used for saving other person's life or can be used in research (Nehmeh, 2013).

\section{Relation with Religion}

Today medicine has reached great success in the treatment and prevention of many illnesses. Currently, scientists and doctors are more focusing on cell technology. New parents now have the option of taking an active role in treating future illness much like a biological insurance policy by referring to cord blood banking (Sheremta, Plant, \& Knopper, 2005). In this context, since 1988, more than 60,000 individual around the world have been treated for hemopoietic malignancies, marrow failure, and immunodeficiency disorders using UCB. This treatment is becoming the current trend in medicine, and therefore it necessitates efficient storage, recovery and expansion techniques as well as deeper knowledge of its action mechanism in order to ensure the safety of patients (Drgreen, 2005). 
This highlights an important ethical controversy that the six main religions; Christianity, Islam, Anglicanism, Judaism, Hinduism, and Buddhism, have with the umbilical cord blood banking. There is little information about whether religious affiliations have any bearing on attitudes to and decisions about its collection, donations, and storage. Thus, people are left, consequently, to identify with a religious tradition whether to discard their child's umbilical cord blood, whether to donate it, or whether to pay to store it (Jorden et al., 2012, p. 497).

To date there has been little, if any, discussion about whether, and if so how, religion might influence lay attitudes and decisions about the use of umbilical cord blood. There are good reasons to believe that it is likely to do so. Many empirical studies have shown that a wide range of health-related beliefs, behaviors and outcomes are influenced by religious affiliations and practices, including in Australia. There is existing evidence of links between religiosity and childbirth and some traditional cultures have special rituals for disposing the umbilical cord, which might problematize the collection and storage of the umbilical cord blood. Lack of any apparent controversy over umbilical cord blood banking suggests that it is largely compatible with religion, but bioethical inquiry should not be confined to controversy, as the grounds for compatibility between medical innovation and religion are also worth investigating (Haws et al., 2012).

Religion can shape attitudes to umbilical cord blood banking not only by imbuing the body with meaning but also by shaping moral obligations to self and others. Religion might encourage or prioritize donation to recipients within one's own family or religious community over there. Each of the six main religions represents consistent with a system of universal blood donation, and the donation of umbilical cord blood is not exceptional in this respect (Jorden et al., 2012, p. 498).

A study was performed in Australia aimed to elicit commentaries on umbilical cord blood banking from experts that represent six major religious traditions. Each expert was invited to comment specifically on the significance of the placenta, the umbilical cord, umbilical cord blood and the birthing process, as well as obligations to community, to family and to self. They were also asked whether the faith had anything to say about ownership and control of umbilical cord blood (ibid, p. 499).

\subsection{Christianity Perspective}

In the Catholic tradition, Tobin (2012) stated that, donation of organs and tissue-including the placenta, umbilical cord or blood obtained from the umbilicus-is warmly encouraged. So, too, is the therapeutic use of stem cells, so long as their use does not involve the destruction of (embryonic) human life. Catholics have reason to reject any talk of ownership of umbilical cord blood (or of the placenta) as this language treats the body or body parts as "property" and introduces a dualism between the person and her or his body which is radically at odds with the way the person-body relationship is understood in the Catholic tradition (p. 450).

Moreover the most significant issue for Catholics in current debates about the donation and banking of umbilical cord blood is to work out how this new resource can be made available to those who need it 
most, both now and in the future knowing that Catholics should maintain that priority should be given to the patient in greater need, and that urgency arising from the imminence of death or from major damage (Tobin, 2012).

\subsection{Islamic Perspective}

In general, blood is treated with great respect in Muslim tradition because of both its symbolic and religious significance. Using/Donating of blood (including umbilical cord blood) is regarded as permissible in Islam because "cupping" (the traditional medical practice of drawing blood-or "bloodletting"- by application of vacuum containers to the skin) was practiced by the Prophet for health reasons. Thus, as long as the blood withdrawn by cupping is not contaminated and satisfies medical conditions ensuring its sterility, transfusion of this blood into others who would benefit from it is permissible.

Serious concerns arise where monetary compensation is sought as Islam does not treat blood or tissue as a commodity and bans its sale. Statements regarding the ownership of blood and placental tissue are also absent as Islam regards God as the owner of an individual's body since it is God that has created human beings (although Muslim jurists may recognize the mother as the "owner" of the womb and, by analogy, the placenta, umbilical cord and cord blood until the time of delivery) (Sachedina, 2012, p. 452).

This phenomena was confirmed by the official office of the religious authority his Eminence, Sayyed Mohammad Hussein Fadlullah where they answered that "This is legally permissible as long as it is used for medical treatment purposes".

\subsection{Anglican Perspective}

Nearly all the relevant applications of umbilical cord blood are generally regarded with wholehearted enthusiasm by evangelical Protestants and Anglicans. It would be rare to find an opponent in these communities said Cameron (2012).

They believe that the good of personhood and relationships and initiates an expansive view of personhood. They favor therapies that support people and uphold their lives. The umbilical cord is a good gift of God's creation that has no particular mystical significance in itself. Therefore they approve uses of it to support people and uphold their lives, as long as these uses do not compromise personhood or relationships (p. 451).

According to early biblical texts, God declared that "the life of a creature is in the blood". Today, few Anglicans believe that this ancient teaching prohibits the consumption of blood products, and by extension, the receipt of a blood transfusion (Cameron, 2012).

\subsection{Jewish Perspective}

Judaism teaches that it is an affirmative precept to heal and that the preservation of life is a paramount value. Although there is discussion of illness and suffering as stimuli for prayer and repentance, Judaism does not take a position that illness, infirmity or incapacity should be embraced or endured as 
a manifestation of God's will. Furthermore, Judaism has encouraged screening and preventative treatment to pre-empt illness and the passing on of congenital defects (Lawrence, 2012, p. 455).

Additionally, Jewish laws impose certain restrictions on what may be undertaken on the Sabbath and festivals, where the preservation of life takes priority, but other treatments are prohibited. Lawrence (2012) added that outside of technical problems which might be entailed by drawing the umbilical cord blood on the Sabbath, there ought therefore to be every opportunity to harvest and bank the umbilical cord blood after delivery and after the umbilical cord has been cut. However, nothing should be done to interfere with or delay the normal processes associated with the birth.

\subsection{Hindu Perspective}

There are two broad approaches to ascertaining Hindu attitudes to umbilical cord blood banking and the utilization of stem cell technology: one exegetical, the other descriptive. Exegetical approaches tend to glean traditional Hindu scriptures with the aim of reconstructing how they might have addressed umbilical cord blood banking had they been faced with the situation. Texts on social theory such as the Laws of Manu ("Mānavadharmaāstra") do prescribe birth rituals, such as the jatakarma. However, beyond saying that the ritual must take place before the umbilical cord is severed. It is notoriously problematic to define "what Hindus believe", or what Hinduism is, because unlike Abrahamic traditions, Hinduism is not based on any unifying creed.

Descriptive approaches, on the other hand, examine how modern Hindus themselves have directly engaged with stem cell technology and theorized their own exegetical approach with less speculative considerations than direct exegesis (McGarrity, 2012, p. 509).

\subsection{Buddhist Perspective}

The collection, storage, donation and use of umbilical cord blood raise issues of concern at a public policy level for Buddhists. In Buddhism, birth is viewed as a natural process. No rituals of purification are prescribed and there is no ceremony of baptism or welcoming of infants as new members of the faith community. No particular significance is attached to the placenta or umbilical cord, or to the residue of blood these contain. In principle, therefore, all of these tissues may be stored and used for medical treatment if they are found to be beneficial. Blood transfusion presents no religious problems for Buddhists and they may be expected to take the same attitude towards umbilical cord blood. While Buddhists may have reservations about the use of embryonic stem cells for research, given their widely held view that individual human life begins at fertilization, no such problems arise in the case of adult stem cells (Keown, 2012, p. 510).

As a conclusion and after examining the different points of views about umbilical cord blood banking, one can notice that there is uniformity across all the religions. It is also likely to increase donation of umbilical cord blood and thereby increase the availability of treatment for many life-threatening conditions. If religious views are covered in training programs about umbilical cord blood banking, health care workers will be able to address patients' and consumers' concerns and provide culturally 
appropriate services.

- Umbilical cord blood banking is generally supported by the Christianity, Anglican, Jewish, Islamic, Hindu and Buddhist faiths.

- These religions do not attach any particular significance to the umbilical cord or placenta, and the collection of umbilical cord blood does not interfere with any religious rituals associated with childbirth.

- None of these religions impose restrictions on the ethnicity of donors or recipients, nor do they prioritize donation within the donor's family or religious community.

- The Christianity, Anglican, Islamic and Buddhist religions provide moral grounds that encourage donation to public umbilical cord blood banks rather than storage of cord blood for private use.

\section{Research Methodology}

The primary objective of this research is to collect on-road data for several aspects related to the cord blood and its banking uses. The below questions were set for the whole study and they represent the core of the whole project:

- Do people know what cord blood is?

- Do people know that they can bank their cord blood for future uses?

- Does religion affect people's attitude and decision towards cord blood banking?

- Can Lebanon be considered a suitable environment for banking cord blood?

\subsection{Research Methodology Techniques}

This paper is exploratory in nature and its mere purpose is to shed light on some aspects that were first not known in our Arab world in general and in Lebanon in specific. The utmost objective of the research was to extract some understanding about the level of awareness if any achieved by the Lebanese citizens. Other objectives came into play and some of those were the relation between banking cord blood and religion since religion is an integral part of Lebanese's society and it plays a major role in every person's decisions whether directly or indirectly. Another piece of the puzzle that we were trying to combine was to relate the education level and cord blood bank on one hand and the financial ability and cord blood bank on another hand. To achieve all the above, a questionnaire has been designed and delivered to the sample via different means.

\subsection{Hypothesis}

Based on literature review and the objective of this research, the following hypotheses have been put into question and these hypotheses will be assessed and measured via SPSS.

Hypothesis 1 and 2 go within descriptive statistics and hypothesis 3 and 4 go beyond descriptive research to study and examine relationships between the respondents' demographics profiles on one hand and their educational and financial level on another hand.

- Hypothesis 1: 
Doctors are not creating awareness to the existence of the use of cord blood banking.

- Hypothesis 2:

The lack of Blood Cord Banks in Lebanon is related to the unstable environmental situations.

- Hypothesis 3:

The respondents' level of education and their readiness and acceptance towards the Blood Cord Bank are dependent.

- Hypothesis 4:

The respondents' financial incomes along with their religious code are related to the willingness to bank cord blood.

In the case of rejection of the above alternative hypotheses, the null ones which represent the negation of the alternatives will be accepted.

\section{Research Design}

As mentioned earlier, a questionnaire has been designed for the purpose of gathering the needed data for analysis.

The questionnaire used in this research paper is based on the survey done by Mary Haws, Kathy Curtis, Tyler Jacob and Travis Price at the Department of Medical Laboratory Sciences in Weber State University Utah. A copy of that survey can be found under the following URL and has been adjusted to cater for the purpose of the research: http://www.weber.edu/WSUImages/DCHPResearch/ mls_2011_12_projects/GRP4_OUR.pdf

Some questions from the initial survey have been omitted and others have been amended in order to reflect the research objectives.

The adjusted questionnaire is made up of 4 parts:

\subsection{Knowledge}

This part is designed to address the respondent's knowledge about cord blood bank. The survey's questions related to this part are questions numbered one to eight.

\subsection{Implementation}

This part is designed in a way that questions would hold implementation issues to be taken in a certain situation and the respondents were given choices that detail what actions would they take when that situation happens. The survey's questions related to this part are questions numbered nine to sixteen.

\subsection{Attitude}

This part is designed to address the respondent's attitude and feelings about cord blood bank. The survey's questions related to this part are questions numbered seventeen to twenty-five.

\subsection{Demographics}

This part is designed to gather data on several sides of the respondents' background including their gender, marital status, educational level, financial income, etc. The survey's questions related to this 
part are questions numbered twenty-six to thirty-six.

The questions included in the survey had several formats, some were dichotomous which instructed the respondents to answer with either a Yes or a No, and others were Likert scale (scale of 5 points was used) which was utilized to measure the respondents' attitudes to which they agree or disagree with a certain situation.

\section{Research Sample Selection}

Before deciding on the sample size, it is important to mention the issue faced which is how to be objective covering a wide range of people in a fast and probabilistic manner in order to get accurate and reliable results. To achieve that, several techniques were used to gather responses to the questionnaire. In fact, 3 ways were used:

- Hard copies: this was the most convenient way of getting responses as hard copies were distributed to respondents who filled it and gave it back. 216 responses were collected following this process.

- Online questionnaire: 70 responses were collected in a period of 1 week, from June $3^{\text {rd }}$ to June $7^{\text {th }} 2013$.

What follows is the URL of the online questionnaire:

https://docs.google.com/forms/d/1VqL_7_YH3RvQzveBm4J8m_kBtqxLEZOjZdER3Pz78wQ/viewfor $\mathrm{m}$

- Soft Copies: 32 responses were collected using the process as the questionnaire was sent via email to the respondents who highlighted their answers and sent it back.

Summing up all the responses from all the means mentioned above, we will get a total of 318 responses.

There were no specific people to which the questionnaire was delivered, the sample included university students, housewives, top level managers, operational managers, specialists, and people from different backgrounds and cultures, and therefore it is fair to say that the sample size had combined the two types of sampling techniques, probabilistic and non-probabilistic.

Convenience sampling was used being one of the non-probabilistic techniques. Responses were collected from direct relatives, friends, classmates, family and coworkers. As for what concerns the probabilistic sampling, the used technique was the simple random sampling and reflected by the online questionnaire which was accessible to the population as a whole.

\section{Results and Finding}

Data gathered from all the collection techniques mentioned before was inserted into SPSS (Statistical Package for Social Science), the software that helps in building and extracting statistical measures including tables, figures, and other descriptive data. 
This test aims at:

- First interpreting the data recorded by analyzing case summaries.

- Second to try and draw attention to the strength of the relationship between the variables, when and if they exist.

- Third to draw the regression line of the variables in question.

In order to extract the needed data, some measurements techniques have been used. Those techniques are:

- Descriptive statistics: contains frequency tables and graphs that show how the data is distributed per each variable. For each variable, the frequency for each encountered value, the percentage, the valid percentage and the cumulative percentage which must total to 100 is shown. This section also summarizes the analysis presented in the frequency table in the form of graphs whether a pie or a bar chart.

- Regression analysis and cross-tabulation techniques: draw attention whether there is a certain relationship between variables, how strong or weak is the relationship and whether it is accepted or not according to the level of error generated. The relationship is populated by running and examining the correlation (bivariate) analysis that shows the dependency between any 2 located variables, and then accepts or rejects if there is a relationship by comparing the error to the Pearson error that is 5\%. For the relationship to be accepted, it must fall below the Pearson error.

\subsection{Results and Findings: Including Tables Using SPSS}

\subsubsection{Demographics Results}

By running the descriptive analysis and after analyzing the demographics data, results have shown (Table 1) that the respondents were $95.9 \%$ females and $4.1 \%$ males. The initial requirement of the researchers was to try and collect as many females' responses as possible (due to the fact that, females are more related to cord blood).

Table 1. Gender Distribution

\begin{tabular}{lll}
\hline Valid & Frequency & Percent \\
\hline Male & 13 & 4.1 \\
Female & 305 & 95.9 \\
Total & 318 & 100.0 \\
\hline
\end{tabular}

As for the age distribution, the outcome was presented in 4 groups in Table 2 as follows:

Table 2. Age Distribution

\begin{tabular}{lll}
\hline Valid & Frequency & Percent \\
\hline Less than 20 & 16 & 5.1 \\
\hline
\end{tabular}




\begin{tabular}{lll}
\hline $21-30$ & 198 & 62.2 \\
$31-40$ & 77 & 24.1 \\
41 and above & 27 & 8.6 \\
Total & 318 & 100.0 \\
\hline
\end{tabular}

$5.1 \%$ of the respondents were less than 21 years old, $62.2 \%$ were between 21 and 30 years old, $24.1 \%$ were between 31 and 40 and only $8.6 \%$ were above 41 . Therefore $86.3 \%$ of the respondents aged between 21 and 40 and that will help in assuring that the results are based on mature opinions.

Table 3 presents the nationality per country of the research area:

Table 3. Nationality

\begin{tabular}{lll}
\hline Valid & Frequency & Percent \\
\hline Lebanese & 318 & 100.0 \\
Syrian & 0 & \\
Others & 0 & \\
Total & 318 & 100.0 \\
\hline
\end{tabular}

Family income is another variable in the project's measures which is presented by Table 4 .

Table 4. Family Income

\begin{tabular}{lll}
\hline Valid & Frequency & Percent \\
\hline Less than $\$ 800$ & 8 & 2.52 \\
$\$ 801-\$ 1200$ & 52 & 16.35 \\
$\$ 1201-\$ 1700$ & 63 & 19.81 \\
$\$ 1701-\$ 3000$ & 80 & 25.16 \\
Above $\$ 3001$ & 115 & 36.16 \\
Total & 318 & 100.0 \\
\hline
\end{tabular}

Five income distributions were put into question and respondents were asked to define to which category they belonged. The results were that $2.52 \%$ had low family income (less than $\$ 800$ ), $61.4 \%$ had middle income between $\$ 801$ and $\$ 3000$ and 36\% have high income (above \$3001). As far as it concerns the marital status of the sample size, it is indicated by Table 5 as follows: 
Table 5. Marital Status

\begin{tabular}{lll}
\hline Valid & Frequency & Percent \\
\hline Single & 197 & 61.7 \\
Married & 117 & 37 \\
Widowed & 0 & 0 \\
Divorced & 4 & 1.3 \\
Total & 318 & 100.0 \\
\hline
\end{tabular}

Based on (Table 6) 61.7\% were single, $37 \%$ were married and $1.3 \%$ were divorced.

Cross-tabulation between the gender and the marital status were performed. Table 6 presents the outcome as follows:

Table 6. Gender* Marital Status Cross-Tabulation

\begin{tabular}{|c|c|c|c|c|c|}
\hline \multirow[t]{2}{*}{ Count } & \multicolumn{4}{|c|}{ Marital Status } & \multirow[t]{2}{*}{ Tota } \\
\hline & & Single & Married & Divorced & \\
\hline \multirow[t]{2}{*}{ Gender } & Male & 10 & 3 & 0 & 13 \\
\hline & Female & 187 & 114 & 4 & 305 \\
\hline Total & & 197 & 117 & 4 & 318 \\
\hline
\end{tabular}

Out of the $95.9 \%$ females around $61.3 \%$ were single, $37.4 \%$ were married and $1.3 \%$ were divorced.

Table 7 presents the educational levels of the sample size:

Table 7. Highest Degree of Education

\begin{tabular}{lll}
\hline Valid & Frequency & Percent \\
\hline 1 year college/No degree & 18 & 5.66 \\
School degree & 28 & 8.81 \\
Bachelor degree & 161 & 50.63 \\
Master's degree & 93 & 29.24 \\
Doctorate degree & 18 & 5.66 \\
Total & 318 & 100.0 \\
\hline
\end{tabular}

As reflected by Table 7. Almost half the respondents hold bachelor degree 50.63\%, followed by 29.24\% respondents holding a Master's degree and the remaining are distributed among those with only few years at college, school degree and doctorate degree. 


\subsubsection{Knowledge}

This part of the questionnaire is composed of eight questions regarding respondents' knowledge about information related to cord blood bank. The main outcomes are presented below.

Table 8 shows that around $70 \%$ of the respondent had an idea about the uses of umbilical cord in treating some diseases.

Table 8. Using Umbilical Cord for Treatment

\begin{tabular}{lll}
\hline Valid & Frequency & Percent \\
\hline Yes & 222 & 69.81 \\
No & 96 & 30.19 \\
Total & 318 & 100.0 \\
\hline
\end{tabular}

Table 9 shows that most of the doctors are not providing information regarding cord blood bank. Around $87 \%$ of the respondents are not receiving information from their physicians about the uses of cord blood.

Table 9. Receiving Information from Doctors

\begin{tabular}{lll}
\hline Valid & Frequency & Percent \\
\hline Yes & 39 & 12.26 \\
No & 277 & 87.11 \\
No answer & 2 & 0.63 \\
Total & 318 & 100.0 \\
\hline
\end{tabular}

Table 10 shows that only $14.15 \%$ of the respondents have good information about cord blood bank and about $25 \%$ have no idea about it.

Table 10. Respondents' Knowledge Regarding Cord Blood Bank

\begin{tabular}{lll}
\hline Valid & Frequency & Percent \\
\hline Never heard about cord blood banking & 82 & 25.79 \\
Heard about cord blood banking but didn't know what it was & 32 & 10.06 \\
Knew little bit about cord blood banking & 149 & 46.86 \\
Confident in my knowledge of cord blood & 45 & 14.15 \\
Have banked cord blood from previous pregnancy & 8 & 2.54 \\
No answer & 2 & 0.6 \\
Total & 318 & 100.0 \\
\hline
\end{tabular}


Table 11 shows that only $12.26 \%$ of the respondents received information from their physicians that is, from reliable sources. As a conclusion, doctors are not providing enough information about this subject and the majority of respondents may build their attitude toward cord blood banking upon variable sources.

Table 11. Source of Information

\begin{tabular}{lll}
\hline Valid & Frequency & Percent \\
\hline Magazine & 23 & 7.23 \\
TV & 42 & 13.21 \\
Internet & 43 & 13.52 \\
Healthcare provider & 39 & 12.26 \\
Family or friends & 86 & 27.05 \\
Never heard of it before today & 45 & 14.15 \\
Other & 40 & 12.58 \\
Total & 318 & 100.0 \\
\hline
\end{tabular}

\subsubsection{Implementation}

This part of the questionnaire is composed of eight questions regarding respondents' reaction toward cord blood bank. The main outcomes are presented below.

Table 12 shows that more than $50 \%$ of the respondents are interested in knowing the purpose behind doing cord blood banking. And about $22 \%$ would like to know if there is any side effect and any probable risk. This means that more than $70 \%$ of the respondent would like to know the scientific background of these banks.

Table 12. Desirable Information about Cord Blood Banking

\begin{tabular}{lll}
\hline Valid & Frequency & Percent \\
\hline Would not like information & 14 & 4.4 \\
Purpose and uses & 174 & 54.72 \\
How it is collected & 21 & 6.6 \\
Cost of banking & 27 & 8.49 \\
Side effect and risks & 71 & 22.02 \\
Other & 12 & 3.77 \\
Total & 318 & 100.0 \\
\hline
\end{tabular}

Table 13 shows that more than $50 \%$ of the respondents would not be influenced by their religious beliefs. In the contrary only $2.5 \%$ would be influenced. 
Table 13. Influences of Religious Beliefs

\begin{tabular}{lll}
\hline Valid & Frequency & Percent \\
\hline Wouldn't influence & 171 & 53.77 \\
Might influence & 32 & 10.06 \\
Would definitely influence & 8 & 2.52 \\
Don't know my religion's opinion & 85 & 26.73 \\
No opinion & 22 & 6.92 \\
Total & 318 & 100.0 \\
\hline
\end{tabular}

Table 14 shows that the respondents' opinion toward the suitability of opening cord blood bank in Lebanon is almost equal between agreeing and disagreeing.

Table 14. Suitability of Lebanese Environment for Banking

\begin{tabular}{lll}
\hline Valid & Frequency & Percent \\
\hline Yes & 162 & 50.94 \\
No & 153 & 48.11 \\
Total & 318 & 100.0 \\
\hline
\end{tabular}

Table 15 shows that $42 \%$ of the respondents think that the reason behind not having cord blood bank in Lebanon is due to the problems that are related to Lebanon. Also about $40 \%$ believe that there is no stability in Lebanon accordingly such banks can't be open.

Table 15. Reasons behind the Unsuitability

\begin{tabular}{lll}
\hline Valid & Frequency & Percent \\
\hline Don't have trust in the stability & 61 & 38.85 \\
Political Environment & 12 & 7.64 \\
Geographical location & 3 & 1.91 \\
Too many problems related to Lebanon & 66 & 42 \\
Others & 15 & 9.55 \\
Total & 157 & 100.0 \\
\hline
\end{tabular}

Table 16 shows clearly that about $90 \%$ of the respondents are willing if they had the chance and the ability to bank their cord blood. 
Table 16. Bank Your Cord Blood

\begin{tabular}{lll}
\hline Valid & Frequency & Percent \\
\hline Yes & 266 & 89.5 \\
No & 31 & 10.5 \\
Total & 297 & 100.0 \\
\hline
\end{tabular}

Table 17 shows that $60 \%$ of the respondents are not willing to take any bank loan in order to do cord blood banking.

Table 17. Willingness to Take Consumer Loan

\begin{tabular}{lll}
\hline Valid & Frequency & Percent \\
\hline Yes & 121 & 40.0 \\
No & 181 & 60.0 \\
Total & 302 & 100.0 \\
\hline
\end{tabular}

Table 18 indicates that the range of the storage fees runs from $\$ 50$ to $\$ 250$.Moreover,this table shows that the highest percentage is for the range of $\$ 50$ to $\$ 100$, while the lowest is the amount of $\$ 250$.

Table 18. Storage Annual Fees

\begin{tabular}{lll}
\hline Valid & Frequency & Percent \\
\hline Would not pay & 46 & 15.38 \\
$\$ 50-\$ 100$ & 105 & 35.12 \\
$\$ 101-\$ 200$ & 60 & 20.07 \\
$\$ 201-\$ 250$ & 50 & 16.72 \\
More then \$250 & 38 & 12.71 \\
Total & 299 & 100.0 \\
\hline
\end{tabular}

\section{Testing the Hypothesis}

16.1 Testing of Hypothesis 1

Hypothesis 1: Doctors are not creating awareness to the existence of the use of cord blood banking.

Concerning the knowledge of the respondents towards cord blood banking and by running the descriptive analysis it was found that almost half of the respondents $47.15 \%$ had little knowledge about cord blood banking and if we sum this $47.15 \%$ with $25.95 \%$ of those who never heard of cord blood banking before today we conclude that awareness is a serious issue in this subject having $73.1 \%$ of the sampled people with little or no knowledge at all about cord blood banking. Although this type of data is important it is even more important to relate 2 variables for this type of information. 
To come up with a conclusion if doctors are creating the needed awareness, several types of information were considered.

The first type of information concerns the knowledge of the respondents towards cord blood banking and if knowledge exists then if it was provided by their doctors or not. To extract this type of information, cross-tabulation technique was performed and the results are shown below in Table 19.

How would you describe your knowledge of cord blood banking? Has your doctor offered information to you regarding cord blood banking? Cross tabulation:

Table 19. Knowledge vs Offered Information (Cross Tabulation)

\begin{tabular}{llll}
\hline & \multicolumn{2}{l}{$\begin{array}{l}\text { Has your doctor offered information } \\
\text { to you regarding cord blood banking? }\end{array}$} \\
\hline $\begin{array}{l}\text { How would you describe your } \\
\text { knowledge of cord blood banking? }\end{array}$ & No & Total \\
\hline $\begin{array}{l}\text { I've never heard of cord blood banking } \\
\text { before today }\end{array}$ & 1 & 79 & 80 \\
I've heard of cord blood banking but & 1 & $98.8 \%$ & $100.0 \%$ \\
didn't know what it was & $3.1 \%$ & 31 & 32 \\
I knew a little bit about cord blood & 20 & $96.9 \%$ & $100.0 \%$ \\
banking & $13.4 \%$ & 129 & 149 \\
I feel confident in my knowledge of & 12 & $86.6 \%$ & $100.0 \%$ \\
cord blood & $26.7 \%$ & 33 & 45 \\
I've banked cord blood from a previous & 5 & $73.3 \%$ & $100.0 \%$ \\
pregnancy & $62.5 \%$ & 3 & 8 \\
Total & 39 & $37.5 \%$ & $100.0 \%$ \\
& $12.4 \%$ & 275 & 314 \\
\hline
\end{tabular}

Doctors, according to the respondents, have not been very active in creating the required awareness for cord blood banking and this was proven by only $12.4 \%$ of the people who answered yes when asked if their doctors have offered them information regarding cord blood banking.

The results are accepted since Chi square shows that they are statistically significant at $0 \%$ (less than Pearson error) of $5 \%$.

Therefore, the alternative hypothesis those doctors are not creating enough awareness for cord blood banking is accepted.

The second type of information that will focus on the above results (defined in the survey in questions 7 and 8) concerns the knowledge of the respondents towards cord blood banking and if knowledge 
exists where they have heard or learned about it. To achieve and to summarize the respondents' opinion, the project used the multiple variable responses technique since question number 8 in the survey enabled the respondents to choose more than one choice. After that, cross-tabulation was run between the knowledge variable of question 7 and the multiple responses set variable of question 8 .

Results as detailed in Table 20 below have shown that people who have heard of cord blood banking and didn't know what it was and those who had little knowledge about it have acquired their knowledge mostly from family and friends.

Cord Blood Banking Knowledge and Heard Of (Cross tabulation).

Table 20. Knowledge vs Source of Resources

\begin{tabular}{|c|c|c|c|c|c|c|c|c|}
\hline \multirow[b]{2}{*}{ How would you describe your } & \multicolumn{8}{|c|}{ Where did you hear or learn about it? } \\
\hline & Magazine & $\mathrm{TV}$ & Internet & Health care & Family or & never heard & Other & Total \\
\hline knowledge of cord blood & & & & provider & friends & of it before & & \\
\hline banking? & & & & & & today & & \\
\hline I've never heard of cord blood & 3 & 3 & 2 & 0 & 2 & 44 & 2 & 56 \\
\hline banking before today & $5.4 \%$ & $5.4 \%$ & $3.6 \%$ & $.0 \%$ & $3.6 \%$ & $78.6 \%$ & $3.6 \%$ & \\
\hline I've heard of cord blood banking & 1 & 8 & 5 & 2 & 19 & 0 & 1 & 32 \\
\hline but didn't know what it was & $3.1 \%$ & $25.0 \%$ & $15.6 \%$ & $6.3 \%$ & $59.4 \%$ & $.0 \%$ & $3.1 \%$ & \\
\hline I knew a little bit about cord & 12 & 28 & 32 & 23 & 53 & 0 & 31 & 149 \\
\hline blood banking & $8.1 \%$ & $18.8 \%$ & $21.5 \%$ & $15.4 \%$ & $35.6 \%$ & $.0 \%$ & $20.8 \%$ & \\
\hline I feel confident in my knowledge & 6 & 6 & 14 & 7 & 9 & 0 & 15 & 45 \\
\hline of cord blood & $13.3 \%$ & $13.3 \%$ & $31.1 \%$ & $15.6 \%$ & $20.0 \%$ & $.0 \%$ & $33.3 \%$ & \\
\hline I've banked cord blood from a & 0 & 0 & 1 & 7 & 3 & 0 & 1 & 8 \\
\hline previous pregnancy & $.0 \%$ & $.0 \%$ & $12.5 \%$ & $87.5 \%$ & $37.5 \%$ & $.0 \%$ & $12.5 \%$ & \\
\hline Total & 22 & 45 & 54 & 39 & 86 & 44 & 50 & 290 \\
\hline
\end{tabular}

As shown in Table 20 , only 39 cases out of 290 have said that their healthcare provider or doctor have provided information, $13.44 \%(39 * 100 / 290)$ represents a low percentage and this in fact proves that doctors are not creating the needed awareness to the existence of the use of cord blood banking.

16.2 Testing of Hypothesis 2

Hypothesis 2: The lack of Blood Cord Banks in Lebanon is related to the unstable environmental situations.

As shown in Table 14 before, a decision cannot be taken from respondents' opinions on whether the Lebanese environment is suitable for banking cord blood since the percentages are closely to be equal. $51.4 \%$ of the respondents said the Lebanese environment is suitable while $48.6 \%$ have said otherwise. Therefore, a conclusion cannot be extracted from this measure since almost an equal number of 
respondents answered that the Lebanese environment is suitable for banking cord blood and the others otherwise.

\subsection{Testing of Hypothesis 3}

Hypothesis 3: The respondents' level of education and their readiness and acceptance towards the Blood Cord Bank are dependent.

The independent variable in this hypothesis is the level of education or highest degree the respondents earned while the readiness and acceptance to bank cord blood is the dependent variable.

To test this hypothesis, two statistical measures will be run, the bivariate analysis and the regression analysis.

As shown by Table 21, after running the bivariate analysis between the dependent and the independent variable, results indicate that there is absolutely no relationship between level of education and acceptance to bank cord blood. This relationship is not accepted since the correlation is statistically significant at the $5 \%$ Pearson level having the calculated error up to $74 \%$ which is way higher than Pearson correlation. This result has been confirmed by the regression analysis.

As a result, the null hypothesis that the respondents' educational level and the ability to bank cord blood are not related.

Table 21. Correlations

If you had the chance and the Highest

ability to bank your cord blood, Degree

would you convincingly do it?

\begin{tabular}{lllc}
\hline $\begin{array}{l}\text { If you had the chance and the } \\
\text { ability to bank your cord blood, }\end{array}$ & Sig. (2-tailed) & & -.019 \\
would you convincingly do it? & $\mathrm{N}$ & 297 & .740 \\
& & & 295 \\
Highest Degree & Pearson Correlation & -.019 & 1 \\
& Sig. (2-tailed) & .740 & 316 \\
& $\mathrm{~N}$ & 295 & \\
\hline
\end{tabular}

\subsection{Testing of Hypothesis 4}

Hypothesis 4: The respondents' financial incomes along with their religious code are related to the willingness to bank cord blood.

It is of no coincidence that this hypothesis was left to the end of this paper. Religion is a very critical subject in the Arab world and in Lebanon as well, people tend to avoid answering questions that might sabotage their beliefs and those who answer tend to confuse the reader by sometimes providing incorrect answers. Testing the hypothesis was no different, as the data collected were entered into SPSS 
and interpreted before generating the results; one can notice that a decent number of questions that were related to religion were left unanswered.

Therefore before trying to test our above mentioned hypothesis, we will plot hereunder some descriptive statistics about religion which was calculated based on the on-hand data.

First of all, and having said the above, I felt the urge to extract a single number that best describes the respondents' knowledge whether their religion accepts or prohibits cord blood. Respondents were given a 5 Likert scale question on which they were asked to agree or disagree on the above statement. A remarkable $56.2 \%$ percent were reluctant in choosing a side and instead they were neutral in providing their answers.

Second, descriptive analysis was run to determine religion influence on people's decision.

N.B. the related question in the survey was a multiple choice question where respondents were asked to choose one and only one answer. Unfortunately, some people indicated more than one answer and if not all then most of the people who provided more than one answer stated that they do not know their religion's opinion about cord blood in addition to another answer. For those cases, I have assumed that if people do not know their religion's opinion about cord blood then there is no need to provide an additional choice as this answer overrides any other answer. The below results are based on that assumption.

Results have shown that more than half of the respondents counting a total of 169 cases out of 316 or what makes a percentile of $53.5 \%$ stated that their religion beliefs wouldn't influence their decision to bank cord blood. $26.9 \%$ said that they do not possess any information about their religion's position on cord blood, $10.1 \%$ indicated a possible influence while $2.5 \%$ rejected the idea that religion might influence their decision.

A study entitled "Business Ethics and Religion in the Financial Business Sector: Case of Syria" (Hejase, Hamdar, \& Raslan, 2013) looked into the notion of religion and ethics. Moreover, the respondents' knowledge about ethics and religion were analyzed and was found that $55 \%$ of the respondents believe that religion has no influence on people's personality. Personality shape people's decision and hence it also can be said that $55 \%$ of the respondents believe that religion has no influence on people's decisions. Comparing this 55\% percentage with the 53.5\% from this paper, we can conclude that people's views about religion have not change during that period.

Now to test the hypothesis utilized here, regression analysis was run i.e., the independent variables were the financial income and the religious code of the respondents, while the dependent variable was the willingness to bank cord blood.

Table 22 presents the summary of the model of the study as follows: 
Table 22. Model Summary

\begin{tabular}{|c|c|c|c|c|c|c|c|c|c|c|}
\hline \multirow[b]{2}{*}{ Model } & \multirow[b]{2}{*}{$\mathrm{R}$} & \multirow[b]{2}{*}{$\mathrm{R}$} & \multirow[b]{2}{*}{ Adjusted } & \multirow{3}{*}{$\begin{array}{l}\text { Std. Error of } \\
\text { the Estimate }\end{array}$} & \multicolumn{4}{|c|}{ Change Statistics } & & \multirow{2}{*}{$\begin{array}{l}\text { Durbin } \\
\text { Watson }\end{array}$} \\
\hline & & & & & R Square & $\mathrm{F}$ & df1 & df2 & Sig. F & \\
\hline & & Square & R Square & & Change & Change & & & Change & \\
\hline 1 & $.171 \mathrm{a}$ & .029 & .023 & .488 & .029 & 4.387 & 2 & 290 & .013 & 1.814 \\
\hline
\end{tabular}

In the above table the Predictors are: Do you follow your religious code in your daily life? And Family Income. While, the Dependent Variable is: If you had the chance but not the financial ability to bank your cord blood, and are you ready to take a consumer loan in order to do it?

The coefficient of correlation $\mathrm{R}$ is low that shows that the variables are not very good fit together.

F significance of $1.3 \%$ is less than Pearson error of 5\% that means that the data holds highly statistical meaning ( $\mathrm{F}$ is the ratio of explained errors over unexplained errors).

Durbin Watson is a measure if certain points have certain variations between the different data, 1.814 means there is variation. It relates 2 different errors together, error is close to 2 and that means there is a positive relationship.

As indicated by Table 22, the significance error is less than $5 \%$ and that means the relationship is accepted.

The Coefficient is correlation is 0.171 , i.e., the dependent variable is explained by the independent variable up to $17.1 \%$, or in other words the relationship is strong up to $17.1 \%$.

The variation of the independent variables explains the variation of the dependent variable up to $2.3 \%$ as shown by R Square.

Table 23 Presents a detailed presentation of the coefficients of the model as follows:

Table 23. Coefficients

\begin{tabular}{llllll}
\hline Model & \multicolumn{2}{l}{ Unstandardized Coefficients } & Standardized Coefficients & $\mathrm{t}$ & Sig. \\
\hline & $\mathrm{B}$ & Std. Error & Beta & & \\
1 (Constant) & 1.742 & .131 & & 13.291 & .000 \\
Family Income & -.067 & .024 & -.158 & -2.734 & .007 \\
Do you follow your & .029 & .026 & .065 & 1.128 & .260 \\
religious code in your & & & & & \\
daily life? & & & & & \\
\hline
\end{tabular}

The Dependent Variable in the above table is: if you had the chance but not the financial ability to bank your cord blood, and are you ready to take a consumer loan in order to do it?

Unstandardized coefficient: 
The regression equation is of the form: $y=a+b x+c z$

Willingness to take a loan $=1.742-0.67 *$ Family Income $+0.29 *$ Following religious code.

$\mathrm{R}$ squared is 0.023 or $2.3 \%$. For every standard deviation (variation) in the independent variables, there is $2.3 \%$ increase in the willingness to pursue a consumer loan.

Standardized coefficient:

To directly explain the correlation $y=-0.158 \mathrm{x}+0.065 \mathrm{z}$

The statistical significance of the respondents following their religious code is $26 \%$ and that is not acceptable wince it is greater than Pearson error of 5\%.

On the other hand, the statistical significance of the family income is $0.7 \%$ less than $5 \%$ and that means that there is a relationship between the willingness to take a consumer loan with the family income. But that relationship is negative since the correlation $\mathrm{R}$ is negative -0.67 . In other words as family income increases, people tend not to take consumer loans for banking cord blood.

So it could be concluded that the respondents' financial income is negatively related to the willingness to pursue a consumer loan for banking cord blood but following the religious code is not related in any way.

\section{Implementation Issues Results}

As shown in Table 24 below, $34.5 \%$ of the respondents would like their doctor to inform them about the purpose and uses of cord blood, $30.6 \%$ would like to know about the side effects of risks associated with collection of cord blood, followed by $17.2 \%$ and $15.2 \%$ for those who would like to inquire about the cost of banking and the means of collecting cord blood respectively.

Table 24. Information Received Frequencies

\begin{tabular}{lll}
\hline Type of Information Received (by group) & \multicolumn{2}{c}{ Responses } \\
\cline { 2 - 3 } & $\mathrm{N}$ & Percent \\
\cline { 2 - 3 } I would not like information regarding cord blood & 13 & $2.6 \%$ \\
The purpose and uses of cord blood & 175 & $34.5 \%$ \\
How cord blood is collected & 77 & $15.2 \%$ \\
The cost of banking cord blood & 87 & $17.2 \%$ \\
Side effects of risks associated with collection of cord blood & 155 & $30.6 \%$ \\
Total & 507 & $100.0 \%$ \\
\hline
\end{tabular}

Furthermore, respondents were asked the following 2 questions:

- When banking cord blood, there is a start-up fee associated with this service. How much would 
you be willing to pay as an initial cost to store blood cells from the umbilical cord?

- If you were to pursue storing your baby's cord blood at a cord blood bank, how much would you be willing to pay per year for storage?

These two questions were dependent on each other, since if one would like to logically look at it, then it might be fair to say that the people who are willing to pay more money to initially store blood cells, must be willing to pay also more money per year for storage.

While coming up with the below conclusions, the results were determined by assuming that the highest percentage in each category represents the most logical answer:

For those who are willing to pay between $\$ 1000$ and $\$ 2000$ as initial fees are ready to pay between $\$ 50$ and $\$ 100$ per year for storage.

For those who are willing to pay between $\$ 2001$ and $\$ 3000$ as initial fees are ready to pay between either \$101 and \$200 or \$201 and \$250 per year for storage.

For those who are willing to pay above $\$ 3001$ as initial fees are ready to pay between $\$ 201$ and $\$ 250$ per year for storage.

In addition to the above conclusions, the Chi Square Table 25 below shows that there is statistical significance (Pstat is smaller than a $=5 \%$, in fact Pstat is perfect being 0\%) of the relationship between the willingness to pay more money to initially store blood cells with the willingness to pay also more money per year for storage.

Table 25. Chi-Square Tests

\begin{tabular}{llll}
\hline & Value & df & Asymp. Sig. (2-sided) \\
\hline Pearson Chi-Square & $191.305 \mathrm{a}$ & 16 & .000 \\
Likelihood Ratio & 173.733 & 16 & .000 \\
Linear-by-Linear Association & 74.037 & 1 & .000 \\
N of Valid Cases & 299 & & \\
\hline
\end{tabular}

In the above table nine cells about (36.0\%) have expected count less than 5, and the minimum expected count is .89 .

\section{Conclusions in a Nutshell}

To summarize all the conclusions from above:

- Conclusion 1:

Doctors are not creating enough awareness for cord blood banking.

- Conclusion 2:

A conclusion cannot be extracted yet regarding whether the Lebanese environment is suitable for 
banking cord blood or not.

- Conclusion 3:

The respondents' educational level and the ability to bank cord blood are not related.

- Conclusion 4:

The respondents' financial income is negatively related to the willingness to pursue a consumer loan for banking cord blood but following the religious code is not related in any way.

- Conclusion 5:

There is relationship between the willingness to pay more money to initially store blood cells with the willingness to pay also more money per year for storage.

\section{Conclusion}

Despite the fact that the concept of cord blood banking is still not very popular and especially in the Lebanese environment, it is believed by many in its power to save lives. This belief unfortunately has not been translated into action through the evident lack or even absence of cord blood banks or corporations. The reason of this absence cannot be yet determined since no evidence proof could have been extracted in the statistics calculated above. On the other hand, people have always been influenced by religion whether in a direct or indirect way. The latter has also sometimes influence on the childbirth but as shown in this paper it has no relation with the population's decision to bank or not to bank cord blood. The family financial income is negatively related to banking cord blood as the ones who are compensated more tend to show less ability to pursue banking cord blood. The controversy pertaining to this subject will never vanish but should the controversy affect people's minds, influence their decisions and forbid them from banking their babies' cord blood?

\section{References}

Alkindi, S., \& Dennison, D. (2011). Umbilical cord blood banking and transplantation. Sultan Qabous Medical Journal, 11(4), 455-461.

American Association of Blood Bank. (2013). Umbilical Cord Blood Donation. Retrieved June 9, 2013, from http://www.aabb.org/sa/facilities/celltherapy/Pages/cordbloodfaqs.aspx

American Pregnancy Association. (2013). Promoting Pregnancy Wellness: Cord Blood Banking. Retrieved June 9, 2013, from http://www.americanpregnancy.org/labor-and-birth/cord-bloodbanking.html

Baby Center.ca. (2012). Banking your baby's cord blood: An overview. Retrieved June 9, 2013, from http://www.babycenter.com/0_banking-your-babys-cord-blood-an-overview_1362261.bc?showAll $=$ true

Ballen, K. (2010). Challenges in umbilical cord blood stem cell banking for stem cell reviewers and reports. Stem Cell Rev, 6, 8-14. 
Ben-Joseph, E. (2012). Cord-Blood Banking. Retrieved June 9, 2013, from http://www.kidshealth.org/parent/_cancer_center/treatment/cord_blood.html\#

Bill, C. W. (2013). Young cell transplantation program. National Marrow Donor Program: Be The Match. Retrieved June 9, 2013, from http://www.marrow.org/Get_Involved/Donate_ Cord_Blood/How_to_Donate/How_to_Donate.aspx

Blood Works Northwest. (2013). Cord Blood Program. Retrieved May 29, 2013, from http://www.psbc.org/cordblood/index.htm

Bou Youness, N. (2014). Manger Director, Future Health Company.

Cameron, A. (2012). Religious perspectives on umbilical cord blood banking-Anglican perspective. Journal of Law and Medicine, 19(3), 497-511.

Cameron, S., Lorena, C. A., \& Kerridge, I. H. (2013). Ethical and legal issues raised by cord blood banking - the challenges of the new bioeconomy. The Medical Journal of Australia, 199(4), 290-292.

Cells4life.co.uk. (2013). Pioneering heart surgery savers man's life-case study. Retrieved June 14, 2013, from http://www.cells4life.co.uk/why-store-stem-cells/stem-cell-case-studies/

Cells4life.co.uk. (2013). Stem cell eye treatment gives sight back-case study. Retrieved June 14, 2013, from http://www.cells4life.co.uk/why-store-stem-cells/stem-cell-case-studies/

Cells4life.co.uk. (2013). Stem cells cure diabetes-case study. Retrieved June 13, 2013, from http://www.cells4life.co.uk/why-store-stem-cells/stem-cell-case-studies/

Columbo, B. (2012). Advantages and Disadvantages: Cord Blood Banking. Retrieved May 26, 2013, from http://www.ezinearticles.com/?Advantages-And-Disadvantages:-Cord-Blood-Banking\&id= 6986439

Cordblood.com. (2013). Banking with CBR Questions. Retrieved June 9, 2013, from http://www.cordblood.com/best-cord-blood-bank/faqs

Dinc, H., \& Sahin, N. (2009). Pregnant Women's Knowledge and Attitudes about Stem Cells and Cord Blood Banking. International Nursing Review, 56(2), 250-256.

Drgreene.com. (2005). Cord Blood Banking. Retrieved June 04, 2013, from http://www.drgreene.com/more-cord-blood-banking/

Duedatecalculator.org. (2013). An Introduction to Cord Blood. Retrieved May 29, 2013, from http://www.duedatecalculator.org/cord-blood/

Epigee.org. (2013). Disadvantages of Cord Blood Banking. Retrieved June 04, 2013, from http://www.epigee.org/disadvantages-with-cord-blood-banking.html

Gunning, J. (2005). Umbilical cord blood banking-implications for the future. Toxicology and Applied Pharmacology, 207, 583-543.

Haldane, J. (1999). Bioethics and the philosophy of the human body. In L. Gormally (Ed.), Issues for a Catholic Bioethic (p. 77). 
Haws, M., Curtis, K., Jacob, T., \& Price, T. (2012). Knowledge and Perceptions of Cord Blood Donation among Pregnant Women. Department of Medical Laboratory Sciences, Weber State University, Ogden.

Hejase, H. J., Hamdar, B., Raslan, M., Hejase, A. J., \& Beyrouti, N. (2013, April). Business Ethics and Religion in the Financial Business Sector: Case of Syria. Journal of Business \& Management, COES\&RJ-JBM, 1(2), 72-111.

Hess, S. (1997). Cord blood banking: A misunderstood option. Advance for Nurse Practitioners, 5(8), 80.

Jordens, C. F., O’Connor, M. A., Kerridge, I. H., Stewart, C., Cameron, A., Keown, D., ... Lawrence, R. J. (2012). Religious perspectives on umbilical cord blood banking. Journal of Law and Medicine, 19(3), 497-511.

Keown, D. (2012). Religious perspectives on umbilical cord blood banking-Buddhist perspective. Journal of Law and Medicine, 19(3), 497-511.

Lawrence, R. J. (2012). Religious perspectives on umbilical cord blood banking-Lawrence perspective. Journal of Law and Medicine, 19(3), 497-511.

McGarrity, A. (2012). Religious perspectives on umbilical cord blood banking-Hindu perspective. Journal of Law and Medicine, 19(3), 497-511.

Moise, K. (2005). Umbilical cord stem cells. Obstetrics and Gynecology, 106(6), 1939-1407.

Moninger, J. (2010). The cord blood controversy. Parents Magazine. Retrieved June 9, 2013, from http://www.parents.com/pregnancy/my-baby/cord-blood-banking/the-cord-blood-controversy/

Nationalcordbloodprogram.org. (2010). Q\&R Cord Blood. Retrieved June 04, 2013, from http://www.nationalcordbloodprogram.org/qa/what_are_advantages.html

Nehme, N. (2013). PhD in Molecular and Cellular Biology.

Percer, B. (2009). Umbilical cord blood banking: Helping parents make informed choices. Nursing for Women's Health, 13(3), 216-223.

Sachedina, A. (2012). Religious perspectives on umbilical cord blood banking-Islamic perspective. Journal of Law and Medicine, 19(3), 497-511.

Sheremta, L., Plant, M., \& Knoppers, B. M. (2005). The Future of Cord Blood Banking in Canada. Health Law Review. Retrieved June 12, 2013, from http://www.law.ualberta.ca/centres/hlidev1/userfiles/7_Sheremeta-Knoppers-Plant.pdf

Tobin, B. (2012). Religious perspectives on umbilical cord blood banking-Catholic perspective. Journal of Law and Medicine, 19(3), 497-511.

Walter-Wise, R. (2011). Umbilical cord blood: Information for childbirth educators. The Journal of Perinatal Education, 20(1), 54-60.

Wolf, S. (1998). Cord blood banking: A promising new technology. Neonatal Network, 17(4), 5-6. 